\title{
CARDIORESPIRATORY AND NEUROMUSCULAR FITNESS OF FEDERAL HIGHWAY POLICE OFFICERS
}

\author{
APTIDÃO CARDIORRESPIRATÓRIA ENEUROMUSCULARDE POLICIAIS RODOVIÁRIOS FEDERAIS \\ APTITUD CARDIORRESPIRATORIA Y NEUROMUSCULAR DE POLICÍAS DE SEGURIDAD VIAL FEDERALES
}

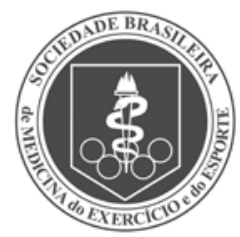

Original Article ARtigo Original Artículo Original
Eduardo Frio Marins 1,2 (Physical Education Professional) Rodrigo Wiltgen Ferreira ${ }^{\top}$ (Physical Education Professional) Fabrício Boscolo Del Vecchio' (Physical Education Professional)

1. Universidade Federal de Pelotas, Upper School of Physical Education, Pelotas, RS, Brazil.

2. Federal Highway Police Department, Brasília, DF, Brazil.

\section{Correspondence:}

Eduardo Frio Marins

Rua Luis de Camões, 625, Bairro

Tablada, Pelotas, RS, Brazil.

96055-630.

dudufrio@gmail.com/eduardo. marins@prf.gov.br

\begin{abstract}
Introduction: Higher levels of physical fitness are associated with better quality of life and indicators of health and performance in police forces. Objective: This study aims to describe and evaluate the level of cardiorespiratory and neuromuscular fitness of a national sample of federal highway patrol officers. Methods: Cross-sectional study with data from 6212 agents of the Federal Highway Police. Endpoints were as follows: abdominal resistance (AR); upper limb muscular resistance (ULMR); upper limb muscle strength (ULMS) and cardiorespiratory fitness (CF). The following independent variables were included: sex; age; geographic region of posting and participation in the Institutional Physical Education Program (IPEP). The linear regression model was used to test the association between endpoints and independent variables. Results: The highest proportion of police officers obtained an excellent score for neuromuscular endpoints (AR: 63.9\% men, 69.6\% women, ULMR: $68.8 \%$ men, $61.8 \%$ women, ULMS: $22.2 \%$ men, $40 \%$ women). In CF, the highest percentage of scores was average and good (respectively, 30.6\% and $43.0 \%$ for men, 39.1\% and 39.2\% for women). Male officers were fitter than female officers, except for the ULMS endpoint. There was a decrease in fitness levels for all endpoints according to age. Police officers from the northern region were fitter than in the other regions. Police officers who were not registered in the IPEP were fitter than those registered. Conclusion: Federal Highway Patrol officers have good levels of fitness, which declines with age. Level of Evidence III; Study of nonconsecutive patients; without consistently applied "gold" reference standard.
\end{abstract}

Keywords: Police; Physical fitness; Physical endurance; Muscle strength; Health.

\section{RESUMO}

Introdução: Maiores níveis de aptidão física estão associados à melhor qualidade de vida e indicadores de saúdee desempenho nas forças policiais. Objetivo: Este estudo visa descrever e avaliar o nível de aptidão cardiorrespiratória e neuromuscular de uma amostra nacional de policiais rodoviários federais. Métodos: Estudo transversal, com dados de 6.212 agentes da Polícia Rodoviária Federal. Como desfechos, consideraram-se: resistência abdominal (RA); resistência muscular de membros superiores (RMMS); força muscular de membros superiores (FMMS) e aptidão cardiorrespiratória (AC). Foram incluidas as seguintes variáveis independentes: sexo, idade, região geográfica de exercício do cargo e participação no Programa de Educação Física Institucional (PEFI). O modelo de regressão linear foi utilizado para testar a associação entre desfechos e variáveis independentes. Resultados: A maior proporção dos policiais obteve conceito excelente para desfechos neuromusculares (RA: 63,9\% homens, 69,6\% mulheres; RMMS: 68,8\% homens, 61,8\% mulheres; FMMS: 22,2\% homens, 40,0\% mulheres). Na AC, maior percentual foi dos conceitos médio e bom (respectivamente, 30,6\% e 43,0\% para homens, 39,1\% e 39,2\% para mulheres). Os policiais do sexo masculino foram mais aptos do que os do sexo feminino, exceto para o desfecho de FMMS. Houve queda de aptidão em todos os desfechos conforme a idade. Os policiais da região norte foram mais aptos em comparação com as demais regiôes. Os policiais não inscritos no PEFI foram mais aptos em comparação com os inscritos. Conclusão: Os Policiais Rodoviários Federais têm bons níveis de aptidão física, que declina com a idade. Nível de evidência III; Estudo de pacientes não consecutivos; sem padrão de referência "ouro" aplicado uniformemente.

Descritores: Polícia; Aptidão física; Resistência física; Força muscular; Saúde.

\section{RESUMEN}

Introducción: Los mayores niveles de aptitud física están asociados a la mejor calidad de vida e indicadores de salud y desempeño en las fuerzas policiales. Objetivo: Este estudio tiene el objetivo de describir y evaluar el nivel de aptitud cardiorrespiratoria y neuromuscular de una muestra nacional de policías de seguridad vial federales. Métodos: Estudio transversal con datos de 6.212 agentes de la Policía de Seguridad Vial Federal. Como resultado, se consideraron: resistencia abdominal (RA); resistencia muscular de miembros superiores (RMMS); fuerza muscular de miembros superiores (FMMS) y aptitud cardiorrespiratoria (AC). Se incluyeron las siguientes variables independientes: sexo; edad; región geográfica de ejercicio del cargo y participación en el Programa de Educación Física Institucional (PEFI). El modelo de regresión lineal se utilizó para probar la asociación entre resultados y variables independientes. Resultados: La mayor proporción de los policías obtuvo concepto excelente para resultados neuromusculares (RA:63,9\% hombres, 69,6\% mujeres, RMMS: 68,8\% hombres, 61,8\% mujeres, FMMS: 22,2\% hombres, 40,0\% mujeres). En la AC, el 
mayor porcentaje se ubicó en los conceptos mediano y bueno (respectivamente, 30,6\% y 43,0\% para hombres, 39,1\% y $39,2 \%$ para mujeres). Los policías de seguridad vial de sexo masculino fueron más aptos que los de sexo femenino, excepto para el resultado de FMMS. Se produjo una caída de aptitud para todos los resultados de acuerdo a la edad. Los policías de la región norte fueron más aptos en comparación con las demás regiones. Los policías no inscritos en el PEFI fueron más aptos en comparación con los inscritos. Conclusión: Los Policías de Seguridad Vial Federales poseen buenos niveles de aptitud física, la cual declina con la edad. Nivel de evidencia III; Estudio de pacientes no consecutivos; sin patrón de referencia "oro" aplicado uniformemente.

Descriptores: Policia; Aptitud física; Resistencia física; Fuerza muscular; Salud.

\section{INTRODUCTION}

In recent decades, the scientific community has been monitoring and reporting the deleterious effects of a sedentary lifestyle on health'1. Thus, physical exercise programs must include cardiorespiratory, strengthening, and flexibility components to maintain and/or improve overall health and physical fitness ${ }^{2}$. Individuals with higher levels of cardiorespiratory fitness and strength have a $57 \%$ and $45 \%$ lower risk of all-cause mortality, respectively, than do those with lower levels of these components of physical fitness ${ }^{3,4}$.

As in the general population, higher levels of physical fitness are associated with a better quality of life and health indicators in public security forces, such as policemen, firemen, and military personne ${ }^{5-7}$. Due to the tactical nature of these professions, these agents are often exposed to situations that involve great physical demands, including running, jumping, crawling, hauling, lifting, and transporting weight ${ }^{8,9}$. Thus, evidence shows the importance of regular monitoring of physical fitness in these occupations, since maintaining acceptable levels of physical fitness is an essential condition for performance of these professions ${ }^{10-13}$.

National publications have reported on indicators of physical fitness among various public security agents ${ }^{14-17}$. However, these studies have limitations in establishing the actual physical fitness level among different public security forces, mainly due to the methodological processes and sample sizes analyzed. Hence comprehensive evidence that would make it possible to infer representative characteristics of physical fitness in this population is still lacking. Accordingly, the objective of the present study was to determine the level of cardiorespiratory and neuromuscular physical fitness in a national sample of the Federal Highway Police (FHP).

\section{MATERIALS AND METHODS}

An observational study was conducted based on retrospective data from the Public Notice 11/2016 of the Federal Highway Police Department (FHPD), which deals with the Physical Fitness Test (PFT) of 2016. The PFT is performed annually, according to regionalized schedules. The PFT data of all police officers were provided by their respective regional authorities and subsequently tabulated in a single document by a specific national commission. All data from the present study were extracted from the FHPD database and analyzed while maintaining the anonymity of the participants.

Any active member of the FHP could volunteer to participate in the PFT 2016, as long as there was no medical contraindication. However, according to Normative Instruction $66 / 2016^{18}$, which regulates the PFT under the FHPD, public servants who I) participate in the Institutional Physical Education Program (IPEP); II) submit to the Assessment of Individual Performance (AIP); and (III) perform selected specific activities, were obliged to participate in the PFT.

The IPEP is an optional membership program that encourages the practice of physical activity outside the work environment. FHP personnel must participate in the annual health programs of the public service, including the Health Patrol ${ }^{19}$ and the $\mathrm{PFT}^{18}$, as well as demonstrate or confirm they are practicing physical activity. In contrast, the FHPD grants one paid hour to a police officer participating in the IPEP, to participate in a physical activity program.

The AIP program evaluates the FHP and measures overall performance, enabling officers to progress in their careers. The annual PFT evaluation is one of the requirements of the final grade of the AIP, i.e., any police officer who wants to advance in the career plan of the FHPD needs to perform the PFT tests.

The Committee on Ethics in Human Research of the School of Physical Education, Federal University of Pelotas, approved this study (No. 64418616.6.0000.5313), allowing the use of retrospective data with anonymity. In addition, the approval for the use of third-party data was supplied by the police institution where this study took place as part of the approval process of the ethics committee. As these data were retrospective and not identifiable, they met the prerequisites for a waiver of informed consent of the participants, because there was no means by which the participants could be identified and consent obtained.

\section{Physical fitness test and outcomes}

The PFT 2016 tests were conducted in the 5 regions of Brazil (North, South, Northeast, Southeast, and Central-West) and the majority of those evaluated were tested at appropriate locations in their work cities. The tests were applied by regional committees composed of police officers, at least one of whom should have graduated in physical education, and was previously trained to perform standardized procedures. The physical evaluations consisted of 4 tests in the following order: (I) 1-minute sit ups; (II) 1-minute push-ups; (III) pull-ups/isometric tests on a fixed bar; and (IV) 12-minute run/walk test. The tests were conducted between March and June 2016, according to the schedule defined by each State.

The registration and input of data were done by the evaluators themselves, in each region, using a pre-formatted worksheet provided by the PFT National Commission. The latter was then responsible for gathering all national data. The database included name, registration, sex, age, participation in IPEP, and the results of physical tests. For the purpose of this manuscript, information about these data was requested from the National Commission and later received by electronic mail.

\section{1-minute Sit-Ups - Abdominal Muscle Resistance}

The abdominal resistance (RM) was measured with the use of a protocol described in previous studies that assessed physical fitness among police officers ${ }^{12,13}$. The individual started the test in supine position on a mat, with knees flexed at $90^{\circ}$ and the feet flat on the ground with the heels together. The arms were crossed on the trunk, with hands resting on the opposite shoulders. Once in position, the individual flexed the trunk, raising the shoulders until the elbows touched the upper portion of the knees, and returned to the initial position. During the test, each candidate received help from an evaluated colleague, who exerted pressure on the feet in order to keep the feet of the evaluated on the 
ground during the entire exercise. On a verbal command from the evaluator, the timer was started and the participant began the test. The individuals were instructed to perform the maximum possible number of abdominal sit-ups in 1 minute.

\section{One-minute Push-Ups - Upper Limb Muscle Resistance}

The upper limb muscle resistance (ULMR) of the FHP was measured using a protocol commonly used in this population ${ }^{8,13,20}$. The male participants started the test in ventral decubitus, with hands and toes on the floor, elbows extended, palms facing forward, shoulders aligned, legs joined, spine erect. With respect to the female participants, only the number of ground supports of the initial position was different from the men, with the procedure performed with hands, knees, and toes on the floor. On a verbal command from the evaluator, the participant performed the push-ups so that the elbows passed the shoulder line, bringing the thorax close to the floor, and then extending them back to the starting position. The officers continued to execute as many repetitions as they could within 1 minute. Participants were allowed to rest in straight-arm position, while keeping their spine erect and allotted time was not exhausted. The test was terminated when the subject was unable to perform the exercise with proper technique or when the allotted time expired.

\section{Pull-Ups/isometry of elbow on fixed bar - Upper Limb Muscle Strength}

The upper limb muscle strength (ULMS) was measured according to a published protocol ${ }^{21}$. Men started in a position of suspension, with elbows extended and hands in prone position (palms of the hands forward). The body was elevated until the chin passed over the bar. After each lift, the officer returned to the initial position with arms fully extended and the body in suspension. The final score was the total number of lifts until exhaustion. The female candidates performed flexion of the elbows without external assistance, with feet in prone position, passing the line of the chin above the top line of the fixed bar, and maintaining isometry for the maximum time possible. The total time in isometry was recorded for later classification. This test was not required to be performed by the police officers, being the only optional test within the PFT in the year 2016.

\section{Twelve-minute run/walk test}

Cardiopulmonary fitness was measured with the 12-minute run/walk test, and maximum oxygen consumption $\left(\mathrm{VO}_{2 \max }\right.$ in $\left.\mathrm{mL}^{\mathrm{kg}} \mathrm{kg}^{-1} \cdot \mathrm{min}^{-1}\right)$ was estimated from the value of the distance covered according to the following previously validated equation $(r=0.91)^{22}: \mathrm{VO}_{2 \max }=$ Distance -504 / 44.78. Among the different indirect field tests for the $\mathrm{VO}_{2 \max }$ prediction, Cooper's 12-minute run test is the most popular and requires only a tape measure to determine the distance travelled in 12 minutes. This test aims at running or walking the longest distance possible on a track in 12 minutes. At the signal of the evaluator, the officer should run or walk the maximum distance during 12 minutes, on a track demarcated every 50 $m$, with the final result recorded as the next mark passed by the officer. Lastly, the classification established by a table in the PFT Public Notice ${ }^{18}$ was carried out. The table is the same used for the general population ${ }^{22}$. The distance covered in Cooper's test showed a significant correlation with directly measured $\mathrm{VO}_{2 \max }(r=0.93, \mathrm{p}<0.001)^{23}$.

\section{Independent variables}

Independent variables related to sex (male or female), age (in complete years), geographic region of occupation (North, Northeast, Midwest, Southeast and South) and participation in the IPEP were included. As an operational decision, the age variable was categorized in decades ( $\leq 29$ years, 30-39 years, $40-49$ years, $\geq 50$ years).

\section{Statistical analyses}

For the associations between outcomes and independent variables, the averages and respective 95\% confidence intervals for each measure of physical fitness and the extracted independent variables of interest were estimated. To test the association, linear regressions were used, based on the type of independent variable. For nominal independent categorical variables (sex, region, and IPEP) the $p$-value was estimated for heterogeneity, while for the ordinal variable (age) the $p$-value was estimated for linear trend. For the specific independent variable of geographic region, statistical differences were also calculated using the Bonferroni post hoc test. The descriptive analyses were stratified by sex. In addition, because the ULMS test was different according to sex, the association of this outcome with independent variables was also performed in a stratified manner.

\section{RESULTS}

The characteristics of the sample according to sex are shown in Table 1. The largest proportion of the sample was between 30 and 39 years of age; $51.1 \%$ were men and $57.2 \%$ were women. With respect to the region of greatest predominance of FHP participants in the PFT, the sex distribution in the Northeast comprised 29.1\% men and 29.8\% women. It should be emphasized that the majority of policemen were registered in the IPEP (76.3\% men and 84.2\% women).

According to the supplemental classification tables used by the $\mathrm{PFT}^{18}$ in regard to physical fitness, most of the male policemen evaluated in Cooper's 12-minute run test were classified as good (43\%), while female officers were classified similarly as fair (39.2\%) and good (39.1\%). In the abdominal resistance test, an excellent classification predominated for both sexes (63.6\% of males and $69.6 \%$ of females). In the ULMR test using push-ups, the majority of men and women were classified as excellent (68.8\% and $61.8 \%$, respectively). In the pull-ups/isometry test, both male and female officers were predominantly in the 10-percentage point decile (22.2\% and $40 \%$, respectively).

The associations between outcomes and independent variables are shown in Table 2. The results show that men have higher cardiorespiratory fitness, abdominal strength, and ULMR. Officers of the Northern region were more able in all outcomes, and officers of the Northeast region had the worst results of physical fitness in all tests performed. There was no difference between the regions in the assessment of ULMS for females. Officers not registered in the IPEP seem to be more qualified than registered officers, except in the ULMS test; registered women achieved better results, while no differences were observed for males.

Finally, there was a decrease in physical fitness according to the categories of age for all tests performed. Figure 1 shows the decrease in the components of physical fitness, measured according to age (presented as continuous numerical variables).

\section{DISCUSSION}

The present FHP study, using data collected in different regions of Brazil, is the first of its kind when considering the population evaluated and sample size. Moreover, it sought to provide knowledge regarding the physical fitness of FHP personnel. As a main finding, it is noteworthy that the participants presented a cardiorespiratory fitness that varied from fair to good according to reference population values; ULMR and strength were excellent, males were superior to females regarding ratings of physical fitness, and a decline in physical fitness with age was observed. Moreover, in this population, officers from the Northern region 
Table 1. Description of the sample, according to gender, of Federal Highway Police, Brazil, 2016. $n=6212$.

\begin{tabular}{|c|c|c|c|c|c|c|}
\hline \multirow{2}{*}{ Variables } & \multicolumn{3}{|c|}{ Male } & \multicolumn{3}{|c|}{ Female } \\
\hline & $\mathrm{N}$ & $\%$ & $(95 \% \mathrm{Cl})$ & $\mathrm{N}$ & $\%$ & $(95 \% \mathrm{Cl})$ \\
\hline \multicolumn{7}{|l|}{ Age } \\
\hline Up to 29 years & 316 & 5,8 & $(5,1-6,3)$ & 55 & 8,6 & $(6,4-10,7)$ \\
\hline $30-39$ & 2848 & 51,1 & $(49,8-52,4)$ & 368 & 57,2 & $(53,5-61,1)$ \\
\hline $40-49$ & 1962 & 35,2 & $(34,0-36,5)$ & 184 & 28,7 & $(25,2-32,2)$ \\
\hline 50 years or more & 444 & 7,9 & $(7,3-8,7)$ & 35 & 5,5 & $(3,7-7,2)$ \\
\hline \multicolumn{7}{|l|}{ Region } \\
\hline South & 1281 & 23,3 & $(22,2-24,4)$ & 113 & 18,3 & $(15,2-21,3)$ \\
\hline Southeast & 1197 & 21,8 & $(20,7-22,9)$ & 128 & 20,7 & $(17,5-23,9)$ \\
\hline Midwest & 828 & 15,1 & $(16,3-22,5)$ & 120 & 19,4 & $(16,3-22,5)$ \\
\hline North & 589 & 10,7 & $(9,9-11,5)$ & 73 & 11,8 & $(9,2-14,3)$ \\
\hline Northeast & 1600 & 29,1 & $(27,9-30,3)$ & 185 & 29,8 & $(26,3-33,5)$ \\
\hline \multicolumn{7}{|l|}{ IPEP } \\
\hline Not registered & 1291 & 23,7 & $(22,5-24,8)$ & 98 & 15,8 & $(12,9-18,7)$ \\
\hline Registered & 4641 & 76,3 & $(75,2-77,5)$ & 521 & 84,2 & $(81,3-87,1)$ \\
\hline \multicolumn{7}{|c|}{ Cardiorespiratory fitness $-\mathrm{VO}_{2 \max }$} \\
\hline Very poor & 331 & 6 & $(5,3-6,6)$ & 32 & 5 & $(3,3-6,7)$ \\
\hline Poor & 487 & 8,8 & $(8,0-9,5)$ & 93 & 14,5 & $(11,8-17,3)$ \\
\hline Fair & 1699 & 30,6 & $(29,4-31,8)$ & 251 & 39,2 & $(35,4-43,0)$ \\
\hline Good & 2388 & 43 & $(41,8-44,4)$ & 250 & 39,1 & $(35,3-42,9)$ \\
\hline Very Good & 641 & 11,6 & $(10,7-12,4)$ & 14 & 2,2 & $(1,1-3,3)$ \\
\hline \multicolumn{7}{|c|}{ Abdominal Resistance } \\
\hline Weak & 189 & 3,4 & $(2,9-3,9)$ & 16 & 2,6 & $(1,3-3,8)$ \\
\hline Below Average & 385 & 7 & $(6,3-7,6)$ & 39 & 6,2 & $(4,3-8,1)$ \\
\hline Fair & 539 & 9,8 & $(9,0-10,5)$ & 56 & 8,9 & $(6,7-11,2)$ \\
\hline Above Average & 893 & 16,2 & $(15,2-17,1)$ & 80 & 12,7 & $(10,1-15,4)$ \\
\hline Excellent & 3523 & 63,6 & $(62,5-65,0)$ & 437 & 69,6 & $(70,0-73,2)$ \\
\hline \multicolumn{7}{|c|}{\begin{tabular}{l|l|l|} 
Upper Limb Muscle Resistance & & \\
\end{tabular}} \\
\hline Poor & 123 & 2,2 & $(1,8-2,6)$ & 7 & 1,1 & $(0,3-1,9)$ \\
\hline Below Average & 260 & 4,7 & $(4,2-5,2)$ & 35 & 5,6 & $(3,8-7,4)$ \\
\hline Fair & 451 & 8,2 & $(7,4-8,9)$ & 58 & 9,2 & $(7,0-11,6)$ \\
\hline Above Average & 890 & 16,1 & $(15,2-17,1)$ & 139 & 22,2 & $(19,0-25,5)$ \\
\hline Excellent & 3792 & 68,8 & $(67,5-70,0)$ & 386 & 61,8 & $(57,9-65,6)$ \\
\hline \multicolumn{7}{|c|}{ Upper Limb Muscle Strength } \\
\hline $0^{*}$ & 45 & 2 & $(1,4-2,6)$ & 0 & 0 & 0 \\
\hline 1 & 179 & 7,9 & $(6,8-9,0)$ & 6 & 13,3 & $(3,0-23,7)$ \\
\hline 2 & 211 & 9,3 & $(8,1-10,5)$ & 3 & 6,8 & $(0,0-14,2)$ \\
\hline 3 & 198 & 8,7 & $(7,6-9,9)$ & 6 & 13,3 & $(3,0-23,7)$ \\
\hline 4 & 205 & 9 & $(7,8-10,2)$ & 2 & 4,4 & $(0,0-10,7)$ \\
\hline 5 & 249 & 11 & $(9,7-12,3)$ & 2 & 4,4 & $(0,0-10,7)$ \\
\hline 6 & 196 & 8,6 & $(7,5-9,8)$ & 3 & 6,8 & $(0,0-14,2)$ \\
\hline 7 & 195 & 8,6 & $(7,4-9,8)$ & 2 & 4,4 & $(0,0-10,7)$ \\
\hline 8 & 162 & 7,1 & $(6,1-8,2)$ & 2 & 4,4 & $(0,0-10,7)$ \\
\hline 9 & 128 & 5,6 & $(4,7-6,6)$ & 1 & 2,2 & $(0,0-6,7)$ \\
\hline 10 & 503 & 22,2 & $(20,4-23,9)$ & 18 & 40 & $(25,1-54,9)$ \\
\hline
\end{tabular}

were fitter than the other brazilian regions and officers registered in the IPEP proved less fit than those not registered.

The statistical analyses revealed significant differences between the measures of physical fitness according to gender, in which female officers had approximately $80 \%, 90 \%$, and $94 \%$ of the aerobic power, and abdominal and upper limb resistance of male FHP personnel, respectively. This difference was slightly lower than the 73\% (aerobic fitness) and 70\% (abdominal strength) reported by Brazilian aeronautic military personne ${ }^{24}$. In addition, a meta-analysis that estimated sex differences in physical abilities within the context of physically demanding occupations (public security, construction, military) found substantially higher results in tests of muscle strength $(d=1.71 ; \delta=1.81)$ and cardiorespiratory endurance $(d=1.81 ; \delta=2.01)$ in favor of men ${ }^{25}$. Regarding neuromuscular fitness, men have better performance due to the morphology of muscle fibers, with larger diameters, greater enzyme activity, and greater proportion of type 2 fibers ${ }^{26,27}$. Men have a higher cardiac output compared to women, due to a higher systolic volume, as well as an increased arteriovenous oxygen difference ${ }^{28}$.

The results of the present study revealed statistical differences in the values of all components of physical fitness in FHP according to age, with better scores for the younger categories compared to the more advanced age groups, which corroborates data found in surveys of Italian firemen recruits $^{29}$ and American policemen ${ }^{13}$. Several studies have reported the decline of aerobic and neuromuscular fitness with advancing age in the general population ${ }^{30,31}$. Broadly, the declines in fitness are caused by the same factors that differentiate the sexes. When comparing individuals with the same physical exercise routines (sedentary or trained), younger individuals have a higher maximum heart rate, increased stroke volume, and increased arteriovenous oxygen difference, when submitted to maximum progressive protocols, compared with older individuals ${ }^{32}$. These factors contribute to greater aerobic fitness. Several mechanisms may explain neuromuscular fitness, but mainly metabolic loss (hormonal, bone mass, among others) and less "muscular quality," represented by the activation of fibers per motor unit associated with the aging process, contribute to lower neuromuscular performance ${ }^{33-35}$.

Few studies have been conducted regarding the aerobic power and muscle strength of national groups of Brazilian police. Considering the nature of the police profession, agents need to have good aerobic fitness and ULMS and FMMI scores to conduct their activities effectively ${ }^{9}$, such as running continuously behind suspects, lifting and dragging victims,

Table 2. Association between the measures of physical fitness and variables of interest in the Federal Highway Police, Brazil, $2016 . \mathrm{n}=6212$.

\begin{tabular}{|c|c|c|c|c|c|c|c|c|c|c|c|c|c|c|c|}
\hline \multirow{3}{*}{ Variables } & \multicolumn{3}{|c|}{$\mathrm{VO}_{2 \max }\left(\mathrm{mL} \cdot \mathrm{kg}^{-1} \cdot \mathrm{min}^{-1}\right)$} & \multicolumn{3}{|c|}{ Abdominal resistance (reps) } & \multicolumn{3}{|c|}{ ULMR (reps) } & \multicolumn{6}{|c|}{ ULMS ** } \\
\hline & \multirow{2}{*}{ Mean } & \multirow{2}{*}{$(95 \% \mathrm{Cl})$} & \multirow{2}{*}{$P$ value } & \multirow{2}{*}{ Mean } & \multirow{2}{*}{$(95 \% \mathrm{Cl})$} & \multirow{2}{*}{$P$ value } & \multirow{2}{*}{ Mean } & \multirow{2}{*}{$(95 \% \mathrm{Cl})$} & \multirow{2}{*}{$P$ value } & \multicolumn{3}{|c|}{ Male (reps) } & \multicolumn{3}{|c|}{ Female (s) } \\
\hline & & & & & & & & & & Mean & $(95 \% \mathrm{Cl})$ & $P$ value & Mean & $(95 \% \mathrm{Cl})$ & $P$ value \\
\hline Sex & & & $<0.001$ & & & $<0,001$ & & & $<0.001$ & & & $<0.001$ & & & \\
\hline Male & 38,0 & $(37,1-38,3)$ & & 33,5 & $(33,3-33,7)$ & & 28.3 & $(28.1-28.6)$ & & 28,3 & $(28,1-28,6)$ & & & & \\
\hline Female & 30,6 & $(30,6-33,1)$ & & 30,1 & $(29,3-30,9)$ & & 26.5 & $(25.7-27.2)$ & & 26,5 & $(25,7-27,2)$ & & & & \\
\hline Age & & & $<0.001^{*}$ & & & $<0,001^{*}$ & & & $<0.001^{*}$ & & & $<0.001^{*}$ & & & $<0.001^{*}$ \\
\hline $\begin{array}{c}\text { Up to } 29 \\
\text { years }\end{array}$ & 40,7 & $(40,0-41,3)$ & & 41,2 & $(40,5-41,9)$ & & 36.5 & $(35.5-37.4)$ & & 36,5 & $(35,5-37,4)$ & & 10,6 & $(10,1-11,1)$ & \\
\hline $30-39$ & 39,0 & $(38,7-39,3)$ & & 35,6 & $(35,3-35,8)$ & & 40.0 & $(30.7-31.3)$ & & 40,0 & $(30,7-31,3)$ & & 9,4 & $(9,2-9,6)$ & \\
\hline $40-49$ & 35,4 & $(35,0-35,8)$ & & 29,7 & $(29,4-30,1)$ & & 24.2 & $(23.8-24.6)$ & & 24,2 & $(23,8-24,6)$ & & 7,2 & $(6,9-7,5)$ & \\
\hline $\begin{array}{l}50 \text { years } \\
\text { or more }\end{array}$ & 31,3 & $(30,5-32,2)$ & & 25,6 & $(24,7-26,4)$ & & 19.3 & $(18.8-20.5)$ & & 19,3 & $(18,8-20,5)$ & & 5,5 & $(4,8-6,2)$ & \\
\hline Region & & & $<0.001 ¥$ & & & $<0,001 £$ & & & $<0.001 £$ & & & $<0.001 £$ & & & $<0.001 \neq$ \\
\hline South & 38,5 & $(38,1-38,9)$ & & 34,1 & $(33,7-34,5)$ & & 28.6 & $(28.2-29.1)$ & & 28,6 & $(28,2-29,1)$ & & 9,1 & $(8,8-9,5)$ & \\
\hline Southeast & 36,8 & $(36,3-37,3)$ & & 32,8 & $(32,4-33,3)$ & & 27.6 & $(27.1-28.1)$ & & 27,6 & $(27,1-28,1)$ & & 8,4 & $(8,1-8,8)$ & \\
\hline Midwest & 38,6 & $(38,0-39,1)$ & & 33,6 & $(33,1-34,0)$ & & 27.8 & $(27.2-28.4)$ & & 27,8 & $(27,2-28,4)$ & & 8,8 & $(8,4-9,2)$ & \\
\hline North & 40,6 & $(40,0-41,1)$ & & 38,2 & $(37,6-38,7)$ & & 33.5 & $(32.7-34.3)$ & & 33,5 & $(32,7-34,3)$ & & 9,8 & $(9,4-10,2)$ & \\
\hline Northeast & 34,8 & $(34,4-35,2)$ & & 30,7 & $(30,2-31,1)$ & & 26.3 & $(25.9-26.8)$ & & 26,3 & $(25,9-26,8)$ & & 7,9 & $(7,6-8,2)$ & \\
\hline IPEP & & & $<0.001$ & & & $<0,001$ & & & $<0.001$ & & & $<0.001$ & & & 0.27 \\
\hline \begin{tabular}{c|} 
Not \\
registered
\end{tabular} & 38,3 & $(37,8-38,7)$ & & 34,2 & $(33,7-34,6)$ & & 29.2 & $(28.7-29.7)$ & & 29,2 & $(28,7-29,7)$ & & 8,6 & $(8,3-8,9)$ & \\
\hline Registered & 36,9 & $(36,6-37,2)$ & & 32,8 & $(32,6-33,1)$ & & 27.8 & $(27.5-28.1)$ & & 27,8 & $(27,5-28,1)$ & & 8,8 & $(8,6-9,0)$ & \\
\hline
\end{tabular}




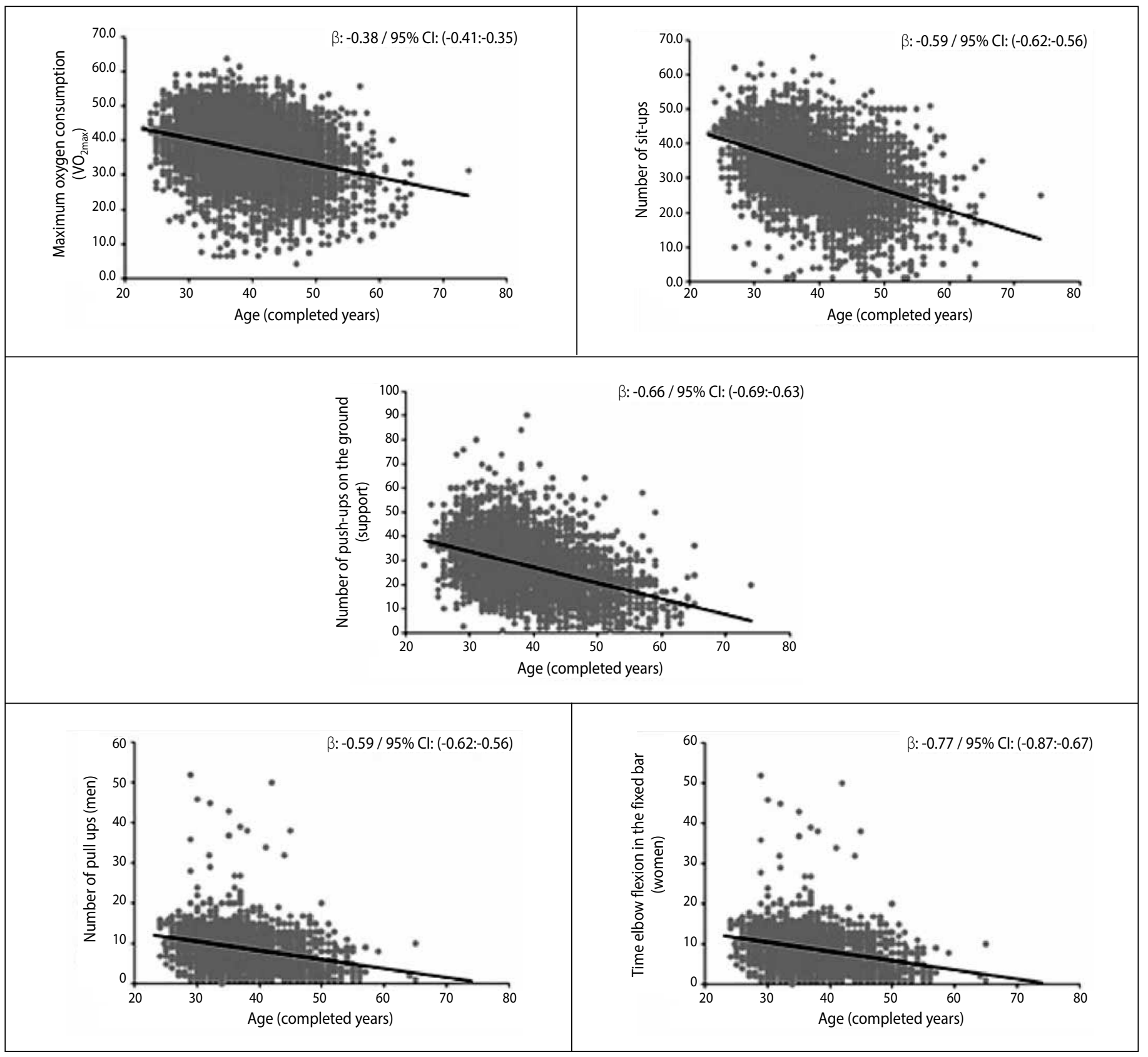

Figure 1. Linear regression analysis of the measures of physical fitness according to age in Federal Highway Police, Brazil, $2016 . \mathrm{n}=6212$.

jumping obstacles, using strength in struggling with suspects, and transporting heavy equipment. Several studies have found a strong correlation between components of physical fitness, particularly strength and muscle power and cardiorespiratory fitness, and performance in occupational police tasks ${ }^{8,12}$. In this context, a recent study using regression analysis showed that the results of the aerobic, ULMR, and trunk test, as well as muscle power, were the best predictors for the time of completion in a police occupational fitness test ${ }^{12}$. Thus, the development of programs of aerobic exercise and strength within the institutional framework is recommended to minimize physical deficiencies.

Interestingly, data from the present study indicate that police officers from the Northern region demonstrated better results in different components of physical fitness, except in muscle strength among women. This region may have stood out because this is where newly trained police officers are placed, as confirmed by a specific statistical test (data not shown). These results corroborate a study carried out with entrants in the Brazilian Armed Forces in different regions, who presented good cardiorespiratory fitness $(51.1 \mathrm{~mL} / \mathrm{kg} / \mathrm{min})$ estimated by the same test ${ }^{16}$. Moreover, in the same study, the Northeast region, as in the present study, achieved the lowest levels of aerobic capacity among the 5 regions studied. We suggest specific investigations for this population in order to understand this association.

The data from the present study identified differences in physical fitness among police officers who were not participating in the program to encourage the practice of physical activity in the IPEP; however, those who participate in the program had lower physical fitness. Due to the cross-sectional design of the study, the lack of more information in the database, and control for possible confounding factors for this association, the present study cannot suggest that the program is not effective in increasing or maintaining the levels of physical fitness of the FHP. As a possible interpretation, one can suggest that police officers not included in the program are more qualified than those registered in the institutional program. These data corroborate a study with FHP from a police station in the south of Brazil, in which police officers participating in a health program presented concerning physical fitness results ${ }^{19}$. 
It should be emphasized that this was the first study to assess the cardiovascular and neuromuscular fitness of FHP personnel with a nationally representative sample. The large sample size increases the possibility of generalizing these results to other police forces. However, some limitations should be noted. First, the authors were limited to physical fitness data supplied by the FHPD, without access to anthropometric data, for example. However, it is known that cardiorespiratory ${ }^{3}$ and neuromuscular ${ }^{4}$ fitness are independent predictors of risk of death from all causes, which reinforces the relevance of the findings of the present study. In addition, the evaluations were performed by different teams in each region, and in locations (athletic tracks) with uneven surfaces and subject to climate differenced in each region, which decreases the standardization of procedures. On the other hand, Normative Instruction 66/2016 of the FHPD ${ }^{18}$ lists all standards and procedures to be followed by the testers and participants in the process of implementation and evaluation of the PFT. Considering the cross-sectional design of this study, new studies should employ a longitudinal design in order to identify the relationship of physical fitness with the time in the police force, as well as its secular trend.

\section{CONCLUSION}

Our results showed that the majority of police officers have fair and good cardiorespiratory fitness, and excellent neuromuscular fitness compared to reference population values. Male Federal Highway Police officers possess higher cardiorespiratory and neuromuscular fitness than do female officers. There was a decline in neuromuscular fitness with age, with values close to one repetition every 2 years. For cardiorespiratory fitness, the decline is close to $3.5 \mathrm{~mL} / \mathrm{kg} / \mathrm{min}$ with every 10 years of age. In addition, police officers in service in the northern region of Brazil, as well as officers non-registered in the IPEP were the fittest.

All authors declare no potential conflict of interest related to this article.

AUTHORS' CONTRIBUTIONS: Each author made significant individual contributions to this manuscript. EFM (0000-0003-4099-4022)*: writing of the article, review and creation of the entire research project. RWF (0000-0002-2616-0083)*: writing and review of the article, data analysis and intellectual concept of the article. FBDV (0000-0003-3771-9660)* writing, review and intellectual concept of the article. ${ }^{*} \mathrm{ORCID}$ (Open Researcher and Contributor ID).

\section{REFERENCES}

1. Kohl HW, Craig CL, Lambert EV, Inoue S, Alkandari JR, Leetongin G, et al. The pandemic of physical inactivity: global action for public health. Lancet Lond Engl. 2012;380(9838):P294-305.

2. Garber CE, Blissmer B, Deschenes MR, Franklin BA, Lamonte MJ, Lee I-M, et al. American College of Sports Medicine position stand. Quantity and quality of exercise for developing and maintaining cardiorespiratory, musculoskeletal, and neuromotor fitness in apparently healthy adults: guidance for prescribing exercise. Med Sci Sports Exerc. 2011;43(7):1334-59.

3. Nocon M, Hiemann T, Müller-Riemenschneider F, Thalau F, Roll S, Willich SN. Association of physical activity with all-cause and cardiovascular mortality: a systematic review and meta-analysis. Eur J Cardiovasc Prev Rehabil. 2008;15(3):239-46.

4. Kraschnewski JL, Sciamanna CN, Poger JM, Rovniak LS, Lehman EB, Cooper AB, et al. Is strength training associated with mortality benefits? A 15year cohort study of US older adults. Prev Med. 2016;87:121-7.

5. Baur DM, Christophi CA, Kales SN. Metabolic syndrome is inversely related to cardiorespiratory fitness in male career firefighters. J Strength Cond Res. 2012;26(9):2331-7.

6. Leischik R, Foshag P, Strauß M, Littwitz H, Garg P, Dworrak B, et al. Aerobic Capacity, Physical Activity and Metabolic Risk Factors in Firefighters Compared with Police Officers and Sedentary Clerks. PloS One. 2015;10(7):e0133113

7. Rajaratnam SMW, Barger LK, Lockley SW, Shea SA, Wang W, Landrigan CP, et al. Sleep disorders, health, and safety in police officers. JAMA. 2011;306(23):2567-78.

8. Beck AQ, Clasey JL, Yates JW, Koebke NC, Palmer TG, Abel MG. Relationship of physical fitness measures vs. occupational physical ability in campus law enforcement officers. J Strength Cond Res. 2015;29(8):2340-50

9. Arvey RD, Landon TE, Nutting SM, Maxwell SE. Development of physical ability tests for police officers: A construct validation approach. J Appl Psychol. 1992;77(6):996-1009.

10. Vanderburgh PM. Occupational relevance and body mass bias in military physical fitness tests. Med Sci Sports Exerc. 2008;40(8):1538-45

11. Stamford BA, Weltman A, Moffatt RJ, Fulco C. Status of police officers with regard to selected cardio-respiratory and body compositional fitness variables. Med Sci Sports. 1978;10(4):294-7.

12. Dawes JJ, Lindsay K, Bero J, Elder C, Kornhauser C, Holmes R. Physical fitness characteristics of high versus low performers on an occupationally specific Physical Agility Test for patrol officers. J Strength Cond Res. 2017;31(10):2808-28.

13. Dawes JJ, Orr RM, Flores RR, Lockie RG, Kornhauser C, Holmes R. A physical fitness profile of state highway patrol officers by gender and age. Ann Occup Environ Med. 2017;29:16.

14. Esteves J, Andrade ML, Gealh L, Andreato LV, de Moraes SF. Caracterização da condição física e fatores de risco cardiovascular de policiais militares rodoviários. Rev Andal Med Deporte. 2014;7(2):66-71.

15. Júnior ACCF, Moreira JD, Coertjens M, Kruel LFM. Características antropométricas e desempenho físico de soldados integrantes da Tropa de Choque. Rev Ed Física. 2016;85(1).

16. Felix GS, Rodrigues PF, Silva RPM. Estudo comparativo da capacidade cardiorrespiratória de ingressantes nas Forças Armadas em cinco regiões do Brasil. Rev Bras Pres Fisiol Exerc. 2016;10(57):149-54.

17. Nogueira EC, Porto LGG, Nogueira RM, Martins WR, Fonseca RMC, Lunardi CC, et al. Body Composition is Strongly Associated With Cardiorespiratory Fitness in a Large Brazilian Military Firefighter Cohort: The Brazilian Firefighters Study. J Strength Cond Res. 2016;30(1):33-8.
18. Polícia Rodoviária Federal. Instrução Normativa n 66, de 07 de março de 2016. Disciplina o Teste de Aptidão Física - TAF, no âmbito da Polícia Rodoviária Federal e dá outras providências.

19. Marins EF, Vecchio FD. Programa Patrulha da Saúde: indicadores de saúde em policiais rodoviários federais. Sci Med. 2017;27(2):25855.

20. Pollock ML. Exercícios na saúde e na doença: avaliação e prescrição para prevenção e reabilitação. Rio de Janeiro: Medsi; 1993.

21. Johnson BL, Nelson JK. Practical measurements for evaluation in physical education. Minnesota: Burgess Publishing Company; 1979

22. Cooper KH. A means of assessing maximal oxygen intake. Correlation between field and treadmil testing. JAMA. 1968;203(3):201-4.

23. Bandyopadhyay A. Validity of cooper's 12-minute run test for estimation of maximum oxygen uptake in male university students. Biol Sport. 2015;32(1):59-63.

24. Pereira ÉF, Teixeira CS. Proposta de valores normativos para avaliação da aptidão física em militares da Aeronáutica. Rev Bras Educ Fís Esp. 2006;20(4):249-56.

25. Courtright SH, McCormick BW, Postlethwaite BE, Reeves CJ, Mount MK. A meta-analysis of sex differences in physical ability: revised estimates and strategies for reducing differences in selection contexts. J Appl Psychol. 2013;98(4):623-41.

26. Simoneau JA, Bouchard C. Human variation in skeletal muscle fiber-type proportion and enzyme activities. Am J Physiol. 1989;257(4 Pt 1):E567-72.

27. Miller AE, MacDougall JD, Tarnopolsky MA, Sale DG. Gender differences in strength and muscle fiber characteristics. Eur J Appl Physiol Occup Physiol. 1993;66(3):254-62.

28. Pate RR, Kriska A. Physiological basis of the sex difference in cardiorespiratory endurance. Sports Med Auckl NZ. 1984;1(2):87-98.

29. Perroni F, Cignitti L, Cortis C, Capranica L. Physical fitness profile of professional Italian firefighters: differences among age groups. Appl Ergon. 2014;45(3):456-61.

30. Lakoski SG, Barlow CE, Farrell SW, Berry JD, Morrow JR, Haskell WL. Impact of body mass index, physica activity, and other clinical factors on cardiorespiratory fitness (from the Cooper Center longitudinal study). Am J Cardiol. 2011;108(1):34-9.

31. Charlier R, Knaeps S, Mertens E, Van Roie E, Delecluse C, Lefevre J, et al. Age-related decline in muscle mass and muscle function in Flemish Caucasians: a 10-year follow-up. Age (Dordr). 2016;38(2):36

32. Ogawa T, Spina RJ, Martin WH, Kohrt WM, Schechtman KB, Holloszy JO, et al. Effects of aging, sex, and physical training on cardiovascular responses to exercise. Circulation. 1992;86(2):494-503.

33. Doherty TJ. The influence of aging and sex on skeletal muscle mass and strength. Curr Opin Clin Nutr Metab Care. 2001;4(6):503-8.

34. Frontera WR, Hughes VA, Fielding RA, Fiatarone MA, Evans WJ, Roubenoff R. Aging of skeletal muscle: a 12-yr longitudinal study. J Appl Physiol (1985). 2000;88(4):1321-6.

35. Goodpaster BH, Park SW, Harris TB, Kritchevsky SB, Nevitt M, Schwartz AV, et al. The loss of skeletal muscle strength, mass, and quality in older adults: the health, aging and body composition study. J Gerontol A Biol Sci. 2006;61(10):1059-64. 